This item is the archived peer-reviewed author-version of:

When revolutionaries grow old : the Museveni babies and the slow death of the liberation

\title{
Reference:
}

Reuss Anna, Titeca Kristof.- When revolutionaries grow old : the Museveni babies and the slow death of the liberation

Third w orld quarterly / Third World Foundation for Social and Economic Studies [London] - ISSN 0143-6597 - 38:10(2017), p. 2347-2366

Full text (Publisher's DOI): https://doi.org/10.1080/01436597.2017.1350101

To cite this reference: https://hdl.handle.net/10067/1451030151162165141 


\title{
Author copy
}

This is the pre-edited author copy. Please refer to the published article: Reuss Anna and Kristof Titeca (2017). When revolutionaries grow old: the Museveni babies and the slow death of the liberation. Third World Quarterly, 38(10), 2347-2366. Doi: http://dx.doi.org/10.1080/01436597.2017.1350101

\section{When revolutionaries grow old: The Museveni babies and the slow death of the liberation}

\author{
Anna Reuss a and Kristof Titeca b \\ a Institute for Development Policy and Management, University of Antwerp, Antwerp, Belgium; \\ Department of Conflict and Development Studies, Ghent University, Ghent, Belgium, \\ Universiteitstraat 8, 9000 Gent, +256 751157 365,anna.e.reuss@gmail.com. \\ b Institute for Development Policy and Management, University of Antwerp, Lange Sint Annastraat \\ 7, 2000 Antwerp, Belgium. +3232655694. Kristof.Titeca@uantwerp.be
}

Anna Reuss is a doctoral student at the Institute for Political Science at the University of Ghent, and the Institute for Development Policy and Management at the University of Antwerp, Belgium. Her research focuses on regime stability and the security sector in Uganda.

Kristof Titeca is an assistant professor at the Institute for Development Policy and Management at the University of Antwerp. His research focuses on conflict and governance in Uganda and the Democratic Republic of Congo, issues on which he has published extensively. 


\title{
When revolutionaries grow old: The Museveni babies and the slow death of the liberation
}

\begin{abstract}
The liberation struggle plays a crucial role in providing legitimacy for post-liberation regimes. This was also the case for the Museveni regime, where the liberation argument provided strong moral authority, and a legitimizing foundation for its patronage and coercion strategies. Yet, what happens when the liberation argument 'grows old', i.e. when the liberation generation elite starts to die or defect; and the young population is no longer impressed by the liberation argument? This article argues that in response to this changing situation, the Museveni regime almost exclusively relies on patronage and coercion, yet increasingly devoid of the legitimizing liberation foundation.
\end{abstract}

Key words: Liberation, Uganda, patronage, democratisation, transition.

In Uganda, Yoweri Museveni's National Resistance Army (NRA) came to power in 1986 after a five year Marxist-inspired guerrilla struggle against the authoritarian Obote government. Hailed for ending decades of military rule and civil war, the liberation struggle prescribes the legitimacy of the President Museveni as a political and military leader, the ruling National Resistance Movement (NRM) party, and the national army born out of the rebel ranks. Three decades after the NRA/M's capture of Kampala, the legacy of the struggle still looms large in symbolic politics: Museveni often refers to himself as 'freedom fighter number one' (Sabalwanyi Number One), and Ugandan political rhetoric is rife with references to the bush war and its achievements - most importantly that the NRM brought peace and stability to the divided country.

Yet, more than 30 years after the NRM liberated Uganda, crucial changes have occurred: a range of key-figures of the liberation struggle have defected; the most recent and notorious examples being a key figure within the army General Sejusa and the former right hand of President Museveni, Prime Minister and NRM Secretary General Amama Mbabazi. Moreover, demographically Uganda went through major changes: $78 \%$ of the population is below 30 years of age, and is therefore born during the NRM regime. ${ }^{1}$ These 'Museveni babies' have never experienced any other president and government, have never experienced nationwide turmoil, and in the face of their search for jobs and livelihoods are less impressed by the 'liberation argument'.

In this article, we set to explain how the regime responded these challenges. In order to do so, we take the following steps: after a theoretical overview of the impact of liberation struggles, we aim to show how the liberation argument played a central role in providing legitimacy to the regime, particularly with regards to the strategies of patronage and coercion. We then explain the changing context (the introduction of the multiparty system, the elite defections, and the changing demographics), and show how the regime responded to these challenges. This article primarily draws 
on the following methodologies: first, it draws on data collected in non-participant observation and informal interviews in Uganda between 2013 and 2016 with a variety of actors: government officials, military officials, journalists, analysts, and so on. Second, it draws on a literature review of both the relevant academic literature and the Ugandan press.

\section{The slow death of revolutionary regimes}

How do regimes maintain power? The material basis for regime support, and more particularly the distribution of resources, has been shown by a variety of authors. Buene de Musquita et al. ${ }^{2}$ show how a 'winning coalition' is needed whose support is kept through both positive inducements and threats of exclusion. Others ${ }^{3}$ further expand on the importance of 'perverse accountability' ${ }^{4}$ in which the distribution of material benefits (subsidies, public goods, and so on) is made contingent on citizen support. This creates voters' support even when the regime is corrupt, and lacks economic growth. ${ }^{5}$ Lust-Okar $^{6}$ shows how, in this context, elections are more frequently contests over access to state resources than actual debates over policy.

Other scholars have emphasized that material support is much more effective in combination with non-material bases of regime support. An obvious form of non-material cohesion and support is ideology, which plays a crucial role in structuring party organisations. ${ }^{7}$ They for example play a crucial role in creating the necessary incentives for the individual party members. ${ }^{8}$ This is particularly the case if the ideology goes together, or is based on, a violent struggle: it has been widely shown how regimes that came into power through a violent struggle have a lasting impact on the stability of these governments, which are often authoritarian regimes. This was first analysed by Samuel Huntington, who showed that the longer the struggle, the more stability for authoritarian regimes once the struggle has been won. ${ }^{9}$ Later on, this was extended, particularly by Levitsky and Way ${ }^{10}$, who convincingly showed that 'sustained, violent and ideologically driven-conflict' is crucial for the cohesion and durability of these regimes ${ }^{11}$, as they have a wider range of repertoires and resources on which they are able to draw ${ }^{12}$.

Concretely, this history of violent struggle has a positive effect on the cohesion and durability in the following ways: the struggle introduces military structures which leave an important legacy with regards to the internal discipline and the cohesion of the regimes in question, allowing these regimes to be more capable of repression and less prone to defection ${ }^{13}$ For example, for the Chinese Communist Party the continued importance of the revolutionary process on 'the techniques of ruleand policy-making ${ }^{14}$ has been shown, giving rise to 'guerilla-style policy-making, ${ }^{15}$. A violent 
struggle does not only leave a heritage of military discipline, but also allows key staff from this struggle to be placed in key state institutions, as personnel is replaced with loyalists, through which power is both concentrated and expanded in the political system ${ }^{16}$. This is particularly the case within the security agencies, who in turn have the benefit of increased obedience and discipline. ${ }^{17}$

The violent struggle in itself also has an impact on feelings of belonging and cohesion for the regime in place: it has produced a particular identity and sense of community, which for example allows to legitimize particular hardships ${ }^{18}$, and because of which party membership is more than a pure formal issue: it is also understood in moral terms ${ }^{19}$. This is particularly the case for the leadership, as the violent struggle gives 'extraordinary legitimacy and unquestioned authority' to a generation of leaders (or individual leaders), which is not only useful for the leaders as such, but which can also be used 'to unify the party and impose discipline during crises' ${ }^{20}$ Often, liberation struggles create a generation of leaders who have a particularly high moral authority. Particularly important is that relationship and alliances which are formed during liberation struggles are crucial, and do have a lasting impact ${ }^{21}$.

However, what happens if the legacy of this liberation struggle (and hence the various forms of non-material cohesion) start to lose their importance? What happens if the founding fathers of this struggle start to die off, and for most of the (young) population, this struggle is something of the past, with little relevance for today? These are the principal questions this article focusses on. ${ }^{22}$

The literature shows the following effects in place. First, gradually an evolution takes place in which non-material sources of cohesion become less prominent, and the nature of the alliances in place change. Key is that when the liberation ideology starts to disappear, these parties or regime develop into more standard regimes, which on the one hand use the spoils of office as the primary means of elite cohesion: as Dorman highlights, the nature of alliances in place are not permanent, and lead to more patrimonial, spoils-oriented exclusive modes of rule ${ }^{23}$. In other words, the 'moral' character of partisan identities weakens, the importance of ideology reduces, and the unifying force of the founding generation disappears. Through this process, identity and ideology are replaced with ambition and patronage, transforming revolutionary parties more and more into 'ordinary parties', vulnerable for defection, corruption and petty factionalism. ${ }^{24}$ In order to address this, additional bases of stability need to be found, such as improved service delivery, economic growth, or institutionalised mechanisms of leadership succession. ${ }^{25}$ Failing to properly develop any of these constitutes a veritable threat to the stability of the regime. ${ }^{26}$ 
Second, legitimacy is a major issue in this whole process: regime legitimacy is largely concentrated within the group of founding members/ leaders of the armed struggle. Once these leaders and veterans of the liberation struggle die, a legitimacy problem occurs: new generations often lack this, as well as the experience for repression. ${ }^{27}$ Often, the new generation of leaders lack an independent power base or constituency to speak of (or constituency at all), but are instead based on the new institutional context of patrimonialism and spoil politics ${ }^{28}$. While this offers a number of advantages for the regime - these new elites' power base is mainly, or only, based on their links with the highest levels of the regime, leading to a stronger control over this new groups of politicians; the disadvantage is an increasingly narrow power-base and disconnect with society: power is increasingly situated and concentrated within an increasingly small group of people. This increases the vulnerability of the regime, by potentially exposing it to frustrated political elites or large sections of the population.

\section{Liberation as a formula for hegemony}

Also in Uganda, the liberation war was crucial for the regime: the liberation war itself, and the sacrifice of those who fought it, has since 1986 provided the core basis of legitimacy for those in power. In this section, we aim to show how this not only was an important was an important identity issue for the regime leadership, but also how the liberation legacy offered a legitimizing rationale for politics of patronage and coercion.

The NRA/M's ascension to power marked the end of two post-independence decades of turmoil, military dictatorship, and civil war under former presidents Milton Obote and Idi Amin that had left the economy in tatters. Museveni and comrades had previously fought Amin as the Front for National Salvation Army (FRONASA) which became a member of the government of the United National Liberation Front (UNLF), a group of loosely allied opposition groups formerly based in exile in Tanzania that had invaded the country together with Tanzanian forces and removed Amin in 1979. After the disputed 1980 elections that returned independence leader Milton Obote to power, former FRONASA cadres, joined by new recruits, took up arms against the second Obote government in early 1981: The National Resistance Army/Movement fought a five year guerrilla struggle in a civil war involving several armed groups and in January 1986 captured Kampala and swore in NRA leader Museveni as President. The NRM government restored peace and stability in large parts of the country and an era of economic growth began. 
The liberation struggle framed the symbolic politics of state re-construction and consolidation of rule. In the Museveni regime, the bush war remained omnipresent: veteran generals are eminent figures of public life, ruling party MPs convene for retreats in fatigues at bonfires, and the NRA's first attack in the bush war continues to be commemorated with an annual army week when soldiers clean towns and engage in other civic action. The importance of the liberation war is more than a legitimating factor for the regime's leadership. In the next sections, we explain how the liberation legacy played a crucial role legitimizing the NRM government's rule, and more particularly in its 'big tent' politics, patronage and military force.

\section{Peace and military force: two sides of the 'liberation argument'}

Until today, support for the NRM government is sought and granted on the basis of the stability dividend of the revolution, or what we call the 'liberation argument'. The regime appeals to citizens' appreciation for the NRA/M's role in ending two decades of military rule and civil war, and bringing about an era of (relative) stability and economic growth. This continues being brought up, up to today. ${ }^{29}$ From the beginning, it resonated with citizens who had experienced Idi Amin's brutal military dictatorship, the turbulent year of quickly succeeding governments following Amin's demise, and the civil war under Obote II, were yearning for stability and economic reconstruction.

These symbolic politics of liberation have attributed a central role the military born out of the fighting force that was credited with liberating the country. As it were the fighters of the NRA, rather than the political superstructure of the movement - the NRM -, who were credited with 'liberating' the country from authoritarian rule, the new national army - the NRA/UPDF - born out of the guerilla fighting force takes a central place in the post-1986 order. The NRA/UPDF was portrayed as the vanguard of the struggle for democracy and development ${ }^{30}$, and, crucially, inseparable from its birthfather, President Museveni. Equally important was that the members of the historical High Command, the NRA's supreme organ, were granted life-time seats on the post-war military High Command and continued to drive strategic decisions behind the scenes. The military was also represented in the legislature, although Museveni did not appoint any bush war commanders to cabinet positions. ${ }^{31}$

The use of military force was 'democratized' through 'patriotic trainings' on the gun open to citizens from all walks of life, and the formation of local defence councils and vigilante groups. This was rationalized as empowerment of citizens for self-defense with reference to past regimes' antipeople armies but crucially gave rise to a pervasive militarization of society that in turn painted the use of military force as normalcy. In sum, taking recourse to the liberation narrative legitimized 
militarization of society and civilian administration. This was equally the case for patronage and 'big tent' politics, which are explained in the next sections.

\section{Big tent politics, patronage and personalisation}

Having captured the capital Kampala in January 1986, the NRM under newly sworn-in President Museveni formed a broad-based government that included members of all established political parties, with the exception of former President Obote's party, the Uganda People's Congress (UPC). The NRA/M blamed past turmoil in the country on sectarian politics that pitted different ethnic and religious groups against each other. ${ }^{32}$ As a consequence, the NRM sought to accommodate all citizens and treat them equally. Ideologically, the NRA/NRM's government reflected this antisectarian stance and formed an inclusive 'big tent' government. Apart from this anti-sectarian stance, there was also another reason for this 'big tent' government: the NRM co-opted established and traditional elites into the new political order to legitimize itself in power. The NRA/M was not in control of all parts of the country and its political-cum-ethnic base for legitimacy was narrow, with its leadership overwhelmingly hailing from western Uganda. Critically, the NRA during the war which was primarily fought out in the Buganda heartland was heavily reliant on the support of the Baganda for manpower, supplies and intelligence. Museveni's war time promise to the Baganda to return their king from exile and restore the kingdom's institutions abolished in 1966 became instructive for NRM politics: The alliance with established political forces, most critically the Buganda kingdom and its supporters, broadened the NRM's legitimacy base and enabled it to consolidate its political and military control over the country. ${ }^{33}$ At the same time, the demands of politics of ethno-regional balancing on the center until today constrains the President's free hand, and for example manifest in never-ceasing spiral of demands for new districts and government recognition of cultural leaders. ${ }^{34}$

Crucially, sectarianism became equated with partisan politics - and party politics: The 1995 constitution effectively banned political party activity and formalized big tent politics in a movement political system under which Ugandans of all political color would come together to spearhead the social and economic development of the nation. ${ }^{35}$ Thus the NRM became the only viable vehicle of political participation, unchallenged by traditional parties.

Consolidation of the post 1986 order, which stretched into the early years of constitutional rule in the late 1990s, prioritized the inclusion of a wide range of actors and constituencies to broaden its basis of legitimacy. Ideological cohesion had to be neglected in favour of big tent politics. Also the institutionalization of state- and party-structures was neglected; the NRM's 
inclusive governance approach became based on patronage politics rather than inclusive policies, and allowed a culture of corruption to quickly take root. Observers early on noted elitist and exclusionary trends, as dozens of first family members, and in-laws became spread across State House, ministries, the army, and parastatals. ${ }^{36}$ Over the next two decades, nepotism and corruption gravely undermined the performance of the public service: Past corruption scandals involve high profile political and military figures, including members of the President's family, ${ }^{37}$ and have led to temporary suspension of donor funding in recent years. The persistent bias of men from Western Uganda, the President's home region, in the senior military leadership has served critics as a symbol of 'western', and more specifically, Banyankole, control over the state. ${ }^{38}$

\section{Multipartyism: the big tent 2.0}

Pressures to re-introduce multi-party politics were rising in the early 2000 s, at the same time when the end of President Museveni's second - and last - constitutional term loomed. The debate over a third term for President Museveni revealed deep rifts within the veteran liberation elite over the personalised political leadership of Museveni. Personalisation of power and bad governance had attracted criticism from within the historical NRA/M's ranks; Over the years, a number of eminent veterans of the liberation struggle, had defected from Museveni and the NRM citing concerns over personal rule and deviation from NRM principles. ${ }^{39}$ In 1999, NRA veteran Kizza Besigye cited corruption, cronyism, and personal rule, running counter to the NRM objective of democratisation in his decision to stand as an alternative candidate in the 2001 elections. ${ }^{40}$ In 2003 , the debate over the lifting of constitutional term limits for the presidency saw open splits at the highest echelons of the party. Prior to the 2005 referendum over the constitutional changes, Museveni sacked three openly critical ministers, and appointed two loyalist senior military officers who had joined the NRA as young men at junior ranks and were after the war groomed by the President, as army commander and Inspector General of Police. ${ }^{41}$ Among those dropped from cabinet after publicly opposing the third term project in 2003 was Museveni's childhood friend, former FRONASA cadre and NRM veteran Eriya Kategaya, then Internal Affairs minister. ${ }^{42}$ In 2005, NRA veteran and the First Lady's in-law, Col. Henry Tumukunde, then an army MP, was arrested and arraigned before the court martial for public criticism of the President over the lifting of term limits in a trial that was to last eight years. ${ }^{43}$

Museveni coupled the popular referendum vote on the re-introduction of multi-party politics with a lifting of presidential term limits, the so-called omnibus bill: In 2005, Ugandans overwhelmingly voted to abandon the no-party system and in the same vein offered their president a constitutional path to more years in power. After the re-introduction of multiparty politics, the NRM changed its formal name to NRM-O to reflect the transition from a national movement to a political 
party organisation. ${ }^{44}$ But the $\mathrm{O}$ was quickly dropped and forgotten about. The abandoned name change illustrates a broader failure to transform the no-party movement's NRM into a competitive, cohesive political party, which did not really function differently as during the no-party movement: the 'big tent' approach and patronage were still at the heart of its functioning.

Beyond the 'liberation argument' - that it brought peace and stability - the NRM did not really have a strong ideological foundation for its rule and institutionalization of the party had long been neglected. It therefore did not fundamentally change its functioning: the re-introduction of the multiparty system did not alter the substance of the NRM and its inclusive approach to government. At the same time, pressures for generational change and criticism over personal leadership within the party were slowly mounting. Therefore, the return to multipartyism drove an expansion of state patronage. Government and the public service were bloated to accommodate as many constituencies as possible after the first opposition challenges to the regime emerged. In 1996, the NRM cabinet counted 21 ministers. Five years later, after President Museveni had fought off his contender, his former personal physician during the bush war, retired Col. Kizza Besigye, cabinet size shot up to 65 members. In 2011, Uganda had the third largest cabinet in the world, with 74 appointed ministers (New Vision, June 8, 2011). Museveni today has more than 140 advisors, an ever increasing number of old friends and foes who remain mostly irrelevant (Observer, September 14, 2016). According to the presidential spokesperson, 'There are reasons why such people are appointed; may be to please certain people, to give you a job or because of the contribution you made earlier.' (Daily Monitor, April 3, 2013) In other words, patronage became a visible and central part of the Museveni regime: public administration and parliament were blown up. At local level, decentralization, encouraged by donors, became a primary tool to rally communities' support. From 56 districts in 2002, Uganda counted 77 districts in 2006, and by 2012, there were 111 districts (New Vision, July 20, 2012). Each new district meant a new budget for the new local administration and more members of parliament. Between 2002 and 2012, parliament grew from 295 to 385 members. ${ }^{45}$ The NRM parliamentary caucus' acquiescence to presidential will was not assured and often had to be bought, at constantly rising costs:

'In 2005, lifting term limits cost 5 million [USD 2900]. Five years later, inducing MPs to support the president took 20 million [USD 8840], and that is not even counting informal expenditures. Members of Parliament are now finding themselves forced to spend much more on their own reelections, meaning that the bill for the regime's efforts to keep itself in office has gone sharply up. ${ }^{46}$ 
Also under multi-party rule, the NRM did not rely on patronage alone for its rule: military force has equally played a significant role in keeping the NRM in power. Whereas patronage was legitimized by the rationale of an inclusive government based on anti-sectarian principles, military force and coercion were equally embedded in a legitimizing narrative of the liberation legacy. This did not only manifest in a militarization of society, but also in a strong preference for military solutions, also in dealing with political protest and opposition. This particularly has been the case since the return to multiparty politics: The regime has increasingly been using the military to crack down on the opposition. This has manifested itself in various ways, but in essence, a heightened display of the martial force of the regime is common in the lead-up to elections. A martial commando under an anti-terrorism task force laid siege on the High Court and prevented the release on bail of opposition leader Besigye's co-accused in a treason case over accusations of forming a rebel group. ${ }^{47}$ The unit dubbed the 'Black Mamba' again stormed the court to re-arrest Besigye's fellow bailed treason suspects. Ahead of the 2011 elections, police introduced the large Field Force Unit, clad in military camouflage, which led the violent crackdown on the popular walk-to-work protests after the 2011 elections (Daily Monitor, September 14, 2016).

In sum, in the above sections we have highlighted how the liberation argument was crucial in providing the legitimacy for the regime, and provided a legitimatising foundation for both patronage and coercion. Yet, the power of this argument slowly started eroding. While patronage, personalisation of power and coercion were from the beginning embedded in the liberation argument, patronage and coercion did not only became increasingly prominent throughout the years, but also became increasingly disconnected from the liberation argument. However, there are limits to this system, as we explain in the next sections.

\section{Generational change: The Museveni babies come of age}

By the time of the 2016 elections, the NRM had been in power for 30 years, the span of a generation. This has important implications for the regime. On the one hand, the party today has to scout for votes among a young population which has never known war the country as a whole in war, and the armed struggle between various regimes. This part of the population is thus less impressed by the 'we brought peace' liberation argument on which the regime bases much of its power. On the other hand, many veterans of the struggle who are bearers of the legitimacy of post-liberation rule have fallen out with the regime - quietly or publicly - over the longevity of Museveni's rule and the unfulfilled promises of the fundamental change ${ }^{48}$; others have retired into private life, or passed away. Prominent public critics of Museveni's leadership among the NRA veterans in Museveni's 
fourth term included Gen. Sejusa (formerly Tinyefuza), then Coordinator for Intelligence Services, who fled into exile before persuaded by State House officials and material incentives to return home and abandon his critical stance, and Major General Biraaro, a long-serving army officer who after years of non-deployment was retired from the army and ran as a presidential candidate in the 2016 elections. ${ }^{49}$ In this section, we outline the generational challenges with which the post-liberation rule of the Museveni regime is confronted.

With $80 \%$ of the population below 30 years of age, youth in numbers are the most powerful voting bloc. These 'Museveni babies' (those born during the Museveni regime) have never experienced any other president and government. An estimated $64-83 \%$ of them are unemployed ${ }^{50}$ and many of them come to the towns in search of livelihoods. This had a decisive impact on the logics of regime support in the ageing post-liberation regime: The 'liberation argument' is less relevant in the face of the coming of age of a generation of post-war youth that has not lived through the violent struggles in Uganda post-colonial history. Instead, it yearns for jobs and development, putting pressure on the labour market and social services, as they constitute the bulk of an estimated 700,000 newly entering the labour market each year. ${ }^{51}$ The latest Afrobarometer results also indicate a strongly growing discontentment about the direction the country is taking, a feeling which is driven by dissatisfaction with economic conditions and declining personal living conditions, and concerns about government effectiveness in addressing citizen priorities drive these perceptions. ${ }^{52}$ The role of, especially urban, youth in regime stability shifted into the focus of the government's attention after the 2011 walk-to-work protests that closely followed the Arab spring. The walk-to-work protests that lasted almost two weeks erupted shortly after the elections were not motivated by the results of the vote but the skyrocketing fuel and commodity prices that made transport fares unaffordable to many urban dwellers (AlJazeera, April 28, 2011). Kampala has since 2006 always recorded an opposition victory, with an gap significantly widening in the past elections: in 2006, Besigye scored $56.7 \%$ of the capital city vote, narrowly trailed by the incumbent with $46.86 \%$ against Museveni's $46.08 \%$, but in 2016, Besigye won $65,93 \%$ of the Kampala vote. ${ }^{53}$ A rapid population growth rate of $3,3 \%{ }^{54}$ then also means a growth of the opposition's key constituency of urban youth, and the segment of the population that has little to lose in protests they know to be violently repressed. Given the lack of opportunities they face in life, and them never having seen the war the regime prides itself in ending, the NRM's traditional post-liberation argument - 'we brought peace and stability' - exudes much less attraction. In sum, the rapid population growth has dramatically altered the environment in which the NRM regime has to scout for votes and deliver services. While the security argument has not become entirely redundant, it is losing its appeal as compared to a generation that experienced 
the Amin and Obote regimes. The extent to which the government fears the wrath of the youth was indicated in various ways: there were serial buy-offs of youth groups as discussed below, and the three day social media shut down starting on the morning of polling day. Moreover, it is also indicated in - as an opposition activist argued - attempts to "conscript them into government support" $" 55$ through crime preventers and the Youth Livelihood Programme Lastly, it is also reflected in the increased use of force in suppressing any attempt for urban (Kampala) street mobilisation by the opposition.

At the same time, the long years of rule ever more pressingly pose the question of leadership succession, especially in a context of development gaps and widespread corruption. When the NRA came to power, President Museveni was legitimized in power by his representation of the collective struggle for liberation, and the expressed support of his fellow (rebel) veterans who had brought about the liberation. As the years went by, and patronage and corruption took root, and the regime repressed opposition activity and political protests, this image changed and Museveni's government became to be viewed less as national but personal system, as we showed above. Internal friction (such as the debate around the third term we illustrated above) and the voter demographics strip the Museveni regime of the air of legitimacy the liberation had endowed it with for many years. Museveni's decades long stay in power has nurtured many grievances among old comrades who reject the personalisation of power, and those who felt they themselves were entitled to a turn at the presidency. By 2013, in the run up to the last presidential elections before Museveni would breach the constitutional age, the loyalty of veterans had eroded substantially.

In other words, the Museveni regime is confronted with substantially changing circumstances, eroding the power of the liberation argument, both among the general society (a young population) as within the regime (liberation veterans who died or no longer support the regime). How did the Museveni regime respond to these challenges? In the next sections, we argue that the reduced appeal of the liberation argument necessitated a further expansion, exaggeration and adaptation of the existing strategies of personalisation, patronage and coercion

\section{Holding the regime together: tightening the grip and marching on}

In response to the erosion of support amongst veterans who could claim legitimacy bestowed upon them by the liberation struggle, Museveni tightened his personal grip on party and security services, and increasingly relied on personal loyalists and patronage to ensure his control. The tightening of personal control over state and government takes two main forms: On the one hand, strategic power 
is increasingly concentrated in the hands of the first family, which is most clearly reflected in the armed forces. On the other hand, young personal loyalists without a claim to historical legitimacy and dependent on the president's goodwill are progressively taking control over positions of influence in party and government.

\section{The revolt of the veterans}

The most visible concentration of power happens by the quick rise in the military ranks of the President's son and, until recently, Special Forces Commander Major General Kainerugaba Muhoozi, who is considered as a potential successor for his father. Since its inception in 2008, the UPDF's Special Forces Command (SFC) with the First Son at the helm had grown significantly in size, capability, and influence; it protects the first family, strategic installations such as the oil wells, takes lead roles in foreign deployments, and supports other forces in containing protest and unrest in Kampala. This however led to increasing tensions, bringing together the dual challenges of eroding veteran loyalty and a young generation yearning for power and change and resulting in the eruption of a lingering succession debate that centred on the President's son.

First, a seasoned veteran NRA commander and eminent figure in the security sector, General Sejusa, in early 2013 openly accused the regime of not only grooming Museveni's son (Major General Muhoozi Kainerugaba) for the presidency, but also of plans to eliminate all those (liberation) veterans in the ruling elite opposed to the quick ascendance of the son (Daily Monitor, May 7, 2013). General Sejusa's leaked letter ignited a public debate in the media about the long rumoured 'Muhoozi project' (The Independent, May 17, 2013). Crucially, the question of a potential succession by Muhoozi Kainerugaba directly linked military grievances to the broader political debate. The alleged 'Muhoozi project' took the personalisation of elite politics to the centre of public debate in the public, and also questioned the prospects of generational change in party and army. The 'SFC' became a representation of the regime elite youth: In the army, and extending its tentacles into State House, the intelligence services and other strategic positions, it is the SFC that presents the youth and generational change (Observer, February 5, 2013). The ensuing debate revealed wider discontent and divisions in the military and among the NRM historicals (Daily Monitor, May 18, 2013) that quickly became defined along support for the veteran General Sejusa versus loyalty to the young Special Forces Commander, or, more broadly, the veterans versus the (regime) youth (Daily Monitor, May 8, 2013). The government's heavy-handed response to media coverage of GenSejusa's accusations - a ten day shutdown of two major media houses - indicated how politically sensitive the regime viewed this conflagration of military and political grievances (Foreign Policy, 
May 22, 2013). Moreover, the regime responded to these events with a grand military reshuffle ${ }^{56}$ that affirmed the end of the veteran era and an increasing concentration of power over the military and the state in the hands of the first family. In 2016, weeks after the elections, Muhoozi was promoted to Major General and Museveni's wife Janet, who had been an MP and state minister for Uganda's least developed region, was appointed education minister (Daily Nation, June 7, 2016) although she had not contested for a parliamentary seat this time. Behind the scenes, the role of Museveni's widely influential brother, bush war hero and retired General Salim Saleh has been growing again over the past years. ${ }^{57}$

Secondly, the longevity and personal nature of Museveni's rule again took centre stage in debate in public and party when the President's right hand-man, Prime Minister and NRM Secretary General Amama Mbabazi, an early NRM cadre and long-time confidante of Museveni, was rumoured to vie for the presidency in the 2016 elections. Unlike General Sejusa, the ultimate regime insider Mbabazi is a civilian veteran who did not fight in the liberation war, and despite a long career in the security portfolio was unlikely to count on a substantive constituency in the military (The East African, October 11, 2014). Nonetheless, the dual public 'defections' of highly influential and prominent veterans ahead of the 2016 elections revealed substantive grievances in ruling party and army. Never before had a veteran of comparable stature openly challenged the presidency to the extent of contesting for Museveni's seat in the elections. Efforts to counter the Mbabazi challenge bound much of the regime's resources in the advent of the elections - and were rewarded with Mbabazi scoring only a meagre $1.5 \%$ at the polls, while allowing Museveni's long-time opponent Besigye to make considerable gains. ${ }^{58}$

\section{The President's young men (and women)}

The distrust in party institutions sown by the Mbabazi challenge saw an acceleration of the elevation of young politicians who owe their loyalty solely to the President and his patronage capacity. Over the years, Museveni had started phasing out the veterans and bringing on board a number of younger cadres. As shown above, the NRM's patronage system was historically underpinned by the legacy and ideology of the liberation struggle, endowing the party with unprecedented legitimacy in the country's history. Many of the men (and women) of the old regime elite had been comrades in arms. In the past, the inner circle of regime loyalists was mainly recruited from amongst veterans of the NRA's armed struggle and the immediate post-1986 government and army, who even if they were junior during the war and the early years could claim some historic legitimacy based on their participation in the liberation struggle. 
This means that today instrumental regime loyalists include many who have no biographical link to the bush war, and whose premier constituency is the President's goodwill. Unlike the NRA/M veterans most of whom regarded themselves as armed political activists and who built party and army from one rebel movement, the young cadres in army and party have not positioned themselves as an ideological force. Expressing mistrust in the systems he built, Museveni has shown a tendency to elevate people who do not have a pre-existent constituency in the community or at national level, and raises them to power. Henceforth the rising stars may use their new found patronage capacity to develop their own constituencies, but their power ultimately is contingent on the pleasure of the presidency. As an example, parliament's youngest member, Evelyn Anite tabled the sole candidature on her knees at the NRM caucus and was later rewarded with a ministerial appointment. Two young former revenue officers turned into vocal regime defenders that quickly rose to positions of influence in cabinet and party. ${ }^{59}$ Still, many of the quickly elevated (like Justine Kasule Lumumba who replaced Mbabazi as NRM Secretary General) are known to lack appeal to voters.

Young regime loyalists are not bound by sentiments of comradeship and decades old personal ties. This gives a new significance and a new quality to patronage. In 2013, each MP received USD 1,880 to 'promote' the controversial Marriage and Divorce Bill in their constituencies (Observer, 31 March 2013). Between May and October 2015, NRM MPs received at least USD 1.64 million to popularise the sole candidature motion and de-campaign presidential candidate Mbabazi. ${ }^{60}$ At the same time, NRM candidates - both old and new- have to fund their campaigns ${ }^{61}$ out of their own pockets, further fuelling incoherence within the party. The result of these dynamics is a lack of cohesion of the NRM, and little ideological bonding with its members; instead it underscores the role of the NRM as a vehicle to access state resources for public service delivery, patronage capacity, and self-enrichment, rather than an ideological home or political representation. As a newspaper joked about politicians' volatile party support, 'Serving people better means being where national resources are distributed.' (New Vision, April 1, 2016). The numbers of hopeful and successful independent candidates who abandon party colours after being defeated in the primaries are constantly rising. ${ }^{62}$

Patronage also plays a critical role in securing youth votes. In the party, factions of the NRM youth, most prominently a group calling itself the 'NRM poor youth', switched allegiance several times motivated by buy-offs (New Vision, August 19, 2015). Several government programmes and projects launched since 2013 targeted youth with material and cash hand-outs ahead of elections. At least 64,000 youth between 2014 and early 2016 benefitted from funding for investments in self- 
employment under the Youth Livelihood Programme (Uganda Media Centre 2015). The implementation of the scheme which was designed as a revolving fund, including selection of beneficiaries, meagre results and low recovery rates, underscored the programme's primary function as a tool of patronage. ${ }^{63}$ After the NRM and Museveni were heavily defeated in the capital city Kampala, President Museveni in the latter half of 2016 launched a new cash distributing exercise, donating up to $300 \mathrm{~m}$ UGX (90,000 USD) at a time to selected youth saving cooperatives (New Vision, September 9, 2016). ${ }^{64}$ In September 2016, Museveni within three weeks donated more than 1.6b UGX (450,000 USD) to Kampala youth groups (Observer, September 14, 2016). At the same time, the regime also used other kind of carrots towards the urban youth, which are not financial in nature. A primary mechanism has been the exemption of certain regulations or taxation. A much illustrated and prominent example has been the attitude of the Museveni regime towards the boda boda (motor taxi) drivers: notwithstanding various attempts of the municipal government to introduce various safety and taxation regulations, they have always remained exempt from these rules - given that these urban youth constitute both an important form of political capital as well a potential threat, the President or national government have directly interfered to protect their interests. Similar dynamics are at play for market vendors. ${ }^{65}$ In other words, the regime is actively looking for ways to make sure not to provoke urban youth, a process in which not only direct cash disbursements play a role, but also the absence of regulation or direct policy intervention to protect the urban youth's interests.

\section{Turning the liberation argument on its head: Fear over gratitude}

The regime did not only rely on an extension of personalisation and patronage, but also on a further extension of coercion to strengthen its rule.

This is particularly important vis-à-vis youth: Youth not only are the most powerful voting bloc but more critically, the opportunity costs for violence among a largely un- and underemployed youth are low. For these reasons, youth took the centre stage in the recent elections. Reference to past achievements of peace and stability after 1986 may lose its attractiveness but the projection of negative impacts on stability and development in case of regime change is still used to discourage opposition support in presidential elections. The liberation argument that claims support for the stability and security dividend of the armed struggle is therefore increasingly used to project negative incentives for regime support, and high costs of opposition support: The NRM government has consistently laboured to convey an image of overwhelming superior power which may only be challenged unsuccessfully and at great cost. ${ }^{66}$ Ahead of the 2016 elections, fears of chaos and violence strewn by senior officials attained new heights. At his closing campaign in February 2016, 
Museveni openly warned voters of instability and violence should the NRM fail to secure a majority and opposition 'disrupt peace' (Daily Monitor, February 17, 2016). NRM Secretary General Justine Kasule Lumumba warned mothers in a village that 'the state will kill your children' if they were to protest in Kampala (Daily Monitor, February 7, 2016). A 2015 opinion poll showed that a majority of Ugandans does not believe that the President would peacefully leave power if defeated at the 2016 polls, yet almost equally as many Ugandans stated they would vote for Museveni again (Daily Monitor, September 6, 2015). Rather because of the stability and peace the NRM brought, today many Ugandans vote for the NRM because the threat of instability invoked by an end of the NRM regime, rather than for the stability and peace the NRM brought. 'They have learnt that Ugandans fear insecurity and they are therefore trying to hoodwink them telling them that if you don't vote this candidate, this will happen and that earns them votes. ${ }^{, 67}$ Support for a candidate is then sought not on the basis of benefits, but the aversion of adverse impacts. 'Wrong voting' also at local level may have imminent repercussions for community development: In 2015, when Museveni told voters in a local by-election that 'I own the money in Uganda', he was warning voters that a vote for the opposition may mean less access to social services for their community (Daily Monitor, January 21, 2015). Inversely, opposition activity, chiefly the FDC, is labelled 'sabotage [of the transformation of the economy] by some political actors' (New Vision, February 6, 2015). Similarly, scrutiny on government by opposition-leaning media is condemned as the promotion of 'chaos' that undermines the nation's achievements since the NRA's liberation (ibid.). In the run-up to the 2016 elections, the projection of fear and intimidation at nationwide levels was spread by a large militia-like outfit recruited by the police. So-called crime preventers had previously emerged in times of elections and crises, but achieved new levels of significance in the campaigns for the 2016 elections; Police throughout 2015 recruited large numbers of crime preventers, mainly male youth. ${ }^{68}$ Police projected numbers of 11 million crime preventers by early 2016 (Daily Monitor, January 25, 2016), although local observers estimated that the true numbers remain below $100,000 .{ }^{69}$ If at large psychologically, the crime preventers, in their highly exaggerated official numbers, spearheaded the countrywide 'mobilisation' of the popular vote; crime preventers were passed out clad in yellow Museveni TShirts, and ferried to NRM rallies. During the campaigns, crime preventers were implicated in clashes with opposition supporters, and intimidation. ${ }^{70}$ By recruiting the militia, the regime also attempted to engage the support of an important voting bloc - un- and underemployed male youth. Yet, in the crime preventers the limits of the need for an ever expanding patronage system became visible: The police chief had originally promised the conscripted youth payment for their service; a promise later retracted by the President who instead offered crime preventers to be primary beneficiaries of Operation Wealth Creation (Daily Monitor, October 20, 2015). Failing to pay the 
crime preventers, about 37,000 of which were transformed into Special Police Constables before polling day, resulted in cases of riots and unrest, while crime preventers early on gained notoriety for engaging in crimes of extortion and robbery (Daily Monitor, November 6, 2015; February 29, 2016).

\section{Conclusions}

In this paper, we have shown the importance of the 'liberation argument' for the Museveni regime. The literature on liberation regimes shows how the history of violent struggle has a positive effect on cohesion and durability in various ways: it leaves a legacy of internal discipline and feelings of belonging; it increases the legitimacy and authority of a particular generation of leaders (the 'liberation leaders'), and so on. Also in Uganda, the liberation character of the regime had these effects: it was crucial in establishing the regime's legitimacy and in keeping the regime together. Yet, what happens if the 'liberation generation' dies off or defects, and when for the youth, the liberation struggle is something of the past? The literature documents that when the 'originals' start dying or defecting, newly recruited leaders' basis of legitimacy is increasingly based on spoil politics, rather than on broader popular legitimacy. As a result, the regime's power base is increasingly narrow, and concentrated within a small group of people - leading to potential frustrations both within and outside of the regime. In order to supplement these increasing neopatrimonial tendencies, additional bases of stability need to be found, such as improved service delivery, economic growth, or institutionalised mechanisms of leadership succession. ${ }^{71}$ Failing to properly develop any of these constitutes a veritable threat to the stability of the regime. ${ }^{72}$

This highlights the dangers of the current situation in Uganda: The changing demographics of the wider population and the disintegration of the veteran elite changed the context in which the Museveni regime must maintain stability. Patronage and coercion have always been key regime strategies, but were historically embedded in the liberation argument that offered a legitimizing rational for 'inclusive' politics of patronage and militarization of civil administration and society. With the reduced attraction of the liberation argument, patronage and coercion are increasingly devoid of a legitimizing foundation. This has led to a vicious circle: the escalation of these strategies led to a reduced legitimacy dividend from the liberation argument, and in turn further exaggerates existing strategies of patronage and coercion.

On the one hand, the patronage system continues to expand. Yet, one can wonder whether the limits of this ever expanding patronage system are beginning to be reached: how long can the strained government budget keep up with the fast rising voter number? Given the strong population growth, and the limited improvement in service delivery, the current situation rather seems to present the 
limits of this continuously expanding system of patronage. As illustrated above, the regime for example failed to pay the crime preventers. Along the same lines, the regime is encountering increasing difficulties to pay for the 'Presidential pledges', in which the President promises, or directly gives, particular sums of money to associations or individuals. As these are unbudgeted, the regime is struggling to provide for all these. ${ }^{73}$ A few recent examples are President Museveni's election promise to provide sanitary pads to school going girls (Daily Monitor, February 15, 2017), or his promise to provide funds to women surviving on selling homebrew alcohol (Daily Monitor, December 6, 2015) - none of which were honoured.

The case of the sanitary pads also shows the second response of the government: coercion. Stella Nyanzi, the Makerere researcher who was a vocal critic of this failed promise, was arrested, brought before court and remanded to prison. More generally, coercion is playing an increasingly central role. While coercion has always been used by the regime, it is increasingly disconnected from the liberation argument. Instead of the army - whose use of coercion was embedded in the liberation narrative - it now is the police which are increasingly used as in instrument of political repression. Unlike the military, it was not dismantled and reconstructed by revolutionary cadres after 1986, but disregarded and neglected for many years. After the 2006 elections that returned the country to multipartyism, the police became increasingly militarized and politicized, while the army became increasingly pre-occupied with peace-keeping. For example, in the 2011 elections and the walk-towork protests afterwards it was large troops of camouflaged, heavily armed police officers that patrolled the streets of Kampala. In 2016, police men severally arrested and lay forty days of siege on Besigye's house, and other candidates the crime preventers recruited, trained and managed by police were at the forefront of the projection of fear among the populace. ${ }^{74}$ “"

In sum, personalisation, patronage and coercion continue to be key strategies for the regime, as shown by the 2016 elections $^{75}$ In the light of changing circumstances in which the liberation argument has become less attractive and relevant, the regime choses an increasingly slippery slope of escalating patronage and coercion, negatively impacting the development of a country as a whole, and unsustainable in the long run.

\footnotetext{
${ }^{1}$ GoU, State of Uganda population report 2012.

2 Bueno de Mesquita, et al., "Political Institutions".

${ }^{3}$ Magaloni, Voting for autocracy.

${ }^{4}$ Stokes, "Perverse Accountability", cited in Magaloni, "Credible power-sharing", 15.

${ }^{5}$ Magaloni, "Credible power-sharing", 15.
} 
${ }^{6}$ Lust-Okar, "Elections under authoritarianism", 468.

${ }^{7}$ Hanson, Post-Imperial Democracies; Huntington, Political order in changing societies.

${ }^{8}$ Hanson, Post-Imperial Democracies, xiv.

${ }^{9}$ Huntington, Political Order, 424-427

${ }^{10}$ Levitsky and Way, "Beyond Patronage"; Levitsky and Way "Revolutionary regimes".

${ }^{11}$ Levitsky and Way, "Beyond Patronage", 870.

${ }^{12}$ Dorman, "Post-liberation Politics", 1097

${ }^{13}$ Levitsky and Way, "Beyond Patronage", 871 and 880

${ }^{14}$ Heilmann and Perry "Embracing uncertainty", 7.

${ }^{15}$ This type of policy-making is characterized by on the one hand creative policies in managing change, and on the other hand a dictatorial, opportunistic and merciless policy style (Heilmann and Perry "Embracing Uncertainty", 7-14).

${ }^{16}$ Huntington, Political Order, 313.

17 'The result is a party-state in which the army, police, and other security agencies are commanded by cadres from the liberation struggle and infused with the ruling party's ideology (...) Such partisan penetration creates a more disciplined coercive apparatus.' Levitsky and Way, "Beyond Patronage", 872)

${ }^{18}$ Huntington, Political Order, 311.

${ }^{19}$ Lebas, From Protest to Parties, 47.

${ }^{20}$ Levitsky and Way, "Beyond Patronage", 871. This has been shown for China (the generation of the Long March, 1934-35); Yugoslavia (Tito and the generation of the Partisan); Mozambique (Frelimo's liberation leaders), and so on. Levitsky and Way "Revolutionary regimes", 9.

${ }^{21}$ Dorman, "Post-liberation Politics", 1092.

${ }^{22}$ In doing so, it has a different objective of the political settlement literature, which aims to undertand the changing nature of political settlements underpinning particular regimes.

${ }^{23}$ Dorman, "Post-liberation Politics", 1099.

${ }^{24}$ Jowitt describes how the Chinese Communist Party leadership gradually was unable to transform its elite members into "combat agents": instead having charismatic impersonal discipline, it became a "neotraditional status organization of cadres primarily oriented to personal, family and material concerns" Jowitt, New World Disorder, 140.

${ }^{25}$ Levitsky and Way, "Beyond Patronage", 880; Levitsky and Way, "Revolutionary regimes", 14.

${ }^{26}$ A success story in this context is the continued resilience of the Chinese regime, a process in which the institutionalization of the elite's succession process played an important role. (Shambough, China's Communist Party, 2-4) as this happened "orderly, peaceful, deliberate and rule-bound" (Nathan, "Authoritarian Resilience", 7).

${ }^{27}$ Levitsky and Way, "Beyond Patronage", 872.

${ }^{28}$ Bratton and van de Walle. Democratic Experiments in Africa, 86.

${ }^{29}$ For example, in 2013 Museveni responds to an interview with Besigye that "The NRA/UPDF brought oturo (to sleep peacefully without worry) not only to the people of Central and Southern Uganda but to all the people of Uganda (North, North-East and Karamoja included).” (New Vision, February 6, 2013)

${ }^{30}$ Kabwegyere, People's Choice, 44.

${ }^{31}$ Government of Uganda, Legal Notice No. 1, January 1986; NRA Statute 1992; UPDF Act 2005. Until Museveni's fourth term, a colloquial notion of the 'High Command' as a supreme advisory and consultative organ of the regime referred to a small inner circle whose composition could vary with the issues at hand around a nucleus of historical members of the High Command, such as Gen. Saleh and Gen. Sejusa (formerly Tinyefuza), then Chief of Defense Forces Gen. Aronda, 'super minister' Mbabazi, and other select veteran personalities.

${ }^{32}$ For example: ““'When we overthrew Idi Amin ourselves, [...] we pleaded with the UPC leaders not to punish the people of West Nile because of the mistakes of Amin as an individual." (State House Uganda, 2015)

${ }^{33}$ Golooba-Mutebi, Frederick "Settling the Buganda Question".

${ }^{34}$ A range of studies have looked at the changing political settlements underlying the Museveni regime, and the way in which the nature of the ruling coalition has "shaped the character and performance of the institutions and actors responsible for delivering development" Golooba-Mutebi and Hickey "Investigating the links between political settlements and inclusive development in Uganda" 3. With regards to Uganda, 
particularly the work of Golooba-Mutebi has been analysing these changing coalitions. Golooba-Mutebi "Collapse, War and Reconstruction in Uganda"; Golooba-Mutebi and Hickey "political settlements and inclusive development"

${ }^{35}$ Barya, "Political parties", 11.

${ }^{36}$ See The Independent (Uganda), March 25, 2009.

${ }^{37}$ Tangri and Mwenda, Elite corruption.

${ }^{38}$ Lindemann, 'Change of Guard',.

${ }^{39}$ Makara, Rakner and Svasand, "Turnaround".

${ }^{40}$ Kalinaki, Kizza Besigye, 148. For a further discussion of the defection of veterans, see also Makara, Rakner and Svasand, "Turnaround".

${ }^{41}$ Makara, Rakner and Svasand, "Turnaround", 193. In 2003, Museveni appointed Aronda Nyakairima army commander and, after the defence reform, Chief of Defence Forces in 2005. The same year, Museveni appointed Kale Kayihura Inspector General of Police. The two loyalist officers had joined the NRA as young men and had risen through the ranks of intelligence.

${ }^{42}$ Kategaya retired into private practice as a lawyer and participated in the formation of today's lead opposition party FDC in 2004 before returning to NRM as a cabinet minister in 2006 after facing severe economic constraints. New Vision, March 8, 2004. Author interview with relative to Kategaya, December 2006.

${ }^{43}$ The period of the trial saw Tumukunde lose political clout and personal wealth before it was brought to a close at a time when Museveni sought to return some of those who had earlier fallen out in the face of the emerging presidential challenge by then PM Mbabazi. After closing of the trial, Tumukunde was promoted to Lieutenant General, retired and put in charge of countering the Mbabazi challenge before appointed security minister in the 2016 cabinet. (Daily Monitor, July 10, 2008. Author interviews with journalist, Kampala, September 2013, military officer, Kampala, May 2015.)

${ }^{44}$ Makara, Rakner and Svasand, "Turnaround", 187, 195.

45 Kintu and Enamu, "Legislative Research Services Adaptation", 4.

${ }^{46}$ Izama and Wilkerson, "Museveni's Triumph and Weakness", 75. Appointments to public office and monetary rewards also play a key role in co-opting opposition supporters and undermining opposition parties' performance at the polls (The Observer, February 6, 2014).

${ }^{47}$ HRW, "Gunmen storm High Court".

${ }^{48}$ To be clear: falling out with the regime does not mean that these actors have joined the opposition, as we clarify for a number of actors.

${ }^{49}$ Author interviews with regime insider, Kampala, May 2015, military officer, Kampala, September 2012 and May 2015.

${ }^{50}$ The Guardian (UK), February 17, 2016.

${ }^{51}$ World Bank, Uganda's Unemployment Challenge.

${ }^{52}$ Ratings of government performance have been declining for almost every sector. Liebowitz et al.

"Going in the wrong direction?"; Liebowitz et al. "Citizen perceptions of democracy in Uganda".

${ }^{53}$ Electoral Commission, "Presidential elections by district".

${ }^{54}$ World Bank, "Population growth".

${ }_{55}^{55}$ Author interview, opposition activist, March 2017.

${ }^{56}$ See New Vision, May 24, 2013.

${ }^{57}$ Saleh has since the 2011 elections taken on various strategic and sensitive assignments, including the conception and running of an army-led nationwide agricultural programme, as well as mediation.

${ }^{58}$ Author interviews with two regime insiders, May \& September 2015, and February 2016.

${ }^{59}$ Frank Tumwebaze and Richard Todwong both worked with Uganda Revenue Authority before joining presidential service and later successfully contesting for parliament on NRM tickets. Both were appointed to cabinet in 2012 and assigned strategic mobilization tasks.

${ }^{60}$ ACFIM 2016, 32.

${ }^{61}$ Vokes "Primaries, patronage, and political personalities"; Wilkins, "Who pays for pakalast?".

${ }^{62}$ Izama and Wilkerson, Museveni's Triumph and Weakness, 74.

${ }^{63}$ Author interviews with NGO director \& electoral commission officer, Eastern Uganda, and town mayor (LCV), Central Uganda, March 2017. 
${ }^{64}$ Opposition leader Besigye encouraged his youth supporters in Kampala to take advantage of the cash bonanza, as Chimpreports reported on May 17, 2016.

${ }^{65}$ Goodfellow and Titeca "Presidential Intervention"; Titeca, "The Commercialization of Uganda's 2011 Election".

${ }^{66}$ President Museveni in 2015 rallied voters in a local election: "I have the money you need for some of the social services but if you make a mistake and vote for the Opposition, you would be blocking the channel because they cannot approach me.” (Daily Monitor, January 21, 2015)

${ }^{67}$ as quoted in The Independent, February 8, 2016.

${ }^{68}$ Tapscott, "Preventing Change and Protecting the Regime", 3

${ }^{69}$ Author interviews, Kampala, January and April 2016.

${ }^{70} \mathrm{HRW}$, "Suspend crime preventers"; Crime preventers were variably promised salaries, and facilitation, but most got nothing at all, nurturing grievances and fuelling riots and protests in some places.

${ }^{71}$ Levitsky and Way, "Beyond Patronage", 880; Levitsky and Way, "Revolutionary regimes", 14.

${ }^{72}$ A success story in this context is the continued resilience of the Chinese regime, a process in which the institutionalization of the elite's succession process played an important role. (Shambough, China's

Communist Party, 2-4) as this happened "orderly, peaceful, deliberate and rule-bound" (Nathan, "Authoritarian Resilience", 7).

${ }^{73}$ Titeca, "The Commercialization of Uganda's 2011 Election".

${ }^{74}$ Among security services, it is the police that attracts the most complaints about human rights abuses lodged with the Uganda Human Rights Commission (followed by private individuals and the UPDF). See: UHRC (UHRC), 18th Annual Report, 2015, published August 2016.

${ }^{75}$ Explaining why he personally distributed the money to Kampala youth, Museveni expressed his lack of confidence in officials: "I have always pledged support but whenever I release money for my pledge, I am always let down by the NRM secretariat and the leaders you elect because they don't deliver what I gave them. This is partly the reason why people are still suffering." (Daily Monitor, September 10, 2016)

\section{References}

Izama, Angelo and Michael Wilkerson. "Uganda: Museveni's Triumph and Weakness", Journal of Democracy, 22, No 3, (2011):64-78.

Barya, John-Jean. "Political Parties, the Movement and the Referendum on Political Systems in Uganda: One Step Forward, Two Steps Back". In Mugaju, Justus \& J. Oloka-Onyango: No-party democracy in Uganda: myths and Realities. Kampala: Fountain Publishers, 2000.

Batanda, Jackee. "A leak in high places puts Ugandans on edge”, Foreign Policy, May 22, 2013, http://foreignpolicy.com/2013/05/22/a-leak-in-high-places-puts-ugandans-on-edge/

Bratton Michael and Nicholas van de Walle. Democratic Experiments in Africa: Regime Transitions in Comparative Perspective. Cambridge, UK: Cambridge Univ. Press, 1997.

Bueno de Mesquita, Bruce, James Morrow, Randolph Siverson, and Alastair Smith. "Political Institutions, Policy Choice and the Survival of Leaders" British Journal of Political Science 32, no. 4 (2002):559-90.

Dorman, Sara R. "Post-liberation Politics in Africa: examining the political legacy of struggle" Third World Quarterly, 27, No. 6 (2006): 1085 - 1101.

Goodfellow, Tom and Kristof Titeca. "Presidential intervention and the changing 'politics of survival' in Kampala's informal economy" Cities 29, No. 4 (2012): 264 - 270.

Hanson, Stephen E. Post-Imperial Democracies: Ideology and Party Formation in Third Republic France, Weimar Germany, and Post-Soviet Russia. New York: Cambridge University Press, 2010. 
Heilmann, Sebastian and Elizabeth J. Perry. "Embracing uncertainty: Guerilla policy style and adaptive governance in China", in S. Heilman and E. Perry (eds). Mao's Invisible Hand: the political foundations of adaptive governance in China. Harvard University Press:1-29, 2011.

Human Rights Watch [HRW]. "Uganda government gunmen storm High Court again”. Human Rights Watch, March 5, 2007. https://www.hrw.org/news/2007/03/05/uganda-government-gunmen-storm-high-court-again

Human Rights Watch [HRW]. "Uganda: Suspend crime preventers". Human Rights Watch, January 12, 2016. https://www.hrw.org/news/2016/01/12/uganda-suspend-crime-preventers

Huntington Samuel. Political order in changing societies. New Haven: Yale University Press, 1968.

Kabwegyere, Tarsis B. People's Choice, People's Power. Challenges and prospects of democracy in Uganda. Kampala, Uganda: Fountain Publishers Ltd., 2000.

Kalinaki, Daniel. Kizza Besigye: Uganda's Unfinished Revolution. Kampala: Dominant Seven Publishers, 2014.

Kintu, Francis and Jonathan Enamu. " Legislative Research Services Adaptation to a Dynamic Political \& Institutional Environment: The Case of Uganda, Parliamentary Research Service (Uganda)", June 2015. http://www.ifla.org/files/assets/services-for-parliaments/preconference/2015/25_francis-kintu_paper.pdf

Lebas, Adrienne. From Protest to Parties. Party-building \& Democratization in Africa. Oxford: Oxford University Press, 2011.

Levitsky, Steven and Lucan Way, "Beyond Patronage: Violent Struggle, Ruling Party Cohesion and Authoritarian Durability," Perspectives on Politics 10 (December 2012): 869-89

Levitsky, Steven and Lucan Way "The durability of Revolutionary regimes" The Journal of Democracy 24, no 3, (2013): 5-17

Liebowitz, Jeremy; Sentamu Robert; Kibirige Francis and Carolyn Logan "Going in the wrong direction? Ugandans report declining government effectiveness". Afrobarometer Briefing Paper No 153. January 2015.

Liebowitz, Jeremy; Sentamu Robert and Francis Kibirige, "Citizen perceptions of democracy in Uganda: the growing gap between expectations and realities". Afrobarometer Briefing Paper No 111. January 2013.

Lindemann, Stefan. 2011. "Just another change of guard? Broad-based politics and civil war in Museveni's Uganda", African Affairs, 110, No 440 (2011):

Lust-Okar, Ellen "Elections under authoritarianism: Preliminary lessons from Jordan", Democratization, 13, no.3, (2006): 456-471

Magaloni, Beatriz. Voting for autocracy. Cambridge, UK: Cambridge University Press, 2006.

Magaloni, Beatriz. "Credible power-sharing and the longevity of authoritarian rule" Comparative Political Studies, 41, no 4-5, (2008): 1-27

Makara, Sabiti, Lise Rakner, and Lars Svåsand. "Turnaround: The National Resistance Movemet and the Reintroduction of a Multiparty System in Uganda", International Political Science Review30, No 2 (2009): 185-204.

"Muhoozi project". The Independent (Uganda), May 17, 2013, https://www.independent.co.ug/muhooziproject/

Nathan, Andrew J. “Authoritarian Resilience” Journal of Democracy, 14, No 1(2003): 6-17. 
Shambaugh, David. China's Communist Party. Atrophy and Adaptation. Washington/Berkeley: Woodrow Wilson Press/ University of Berkeley Press, 2008.

Stokes, Susan. "Perverse accountability: A formal model of machine politics with evidence from Argentina." American Political Science Review, 99 no. 3 (2005): 315-325.

Tapscott, Rebecca. "Preventing Change and Protecting the Regime: Crime Preventers, Local Livelihoods, and the 2016 Ugandan Elections". Justice and Security Research Programme, Paper No.31,April 2016. London: London School of Economics

Titeca, Kristof. "The Commercialization of Uganda's 2011 Election in the Urban Informal Economy: Money, Boda-Bodas and Market Vendors", in, S. Perrot, S. Makara, J. Lafargue, M-A. Fouéré, (eds.) Elections in a hybrid regime. Revisiting the 2011 polls. Kampala: Fountain publishers:178-207, 2014.

Vokes, Richard. "Primaries, patronage, and political personalities in South-western Uganda", Journal of Eastern African Studies, 10, No 4 (2016): 660-676.

Wilkins, Sam. "Who pays for pakalast? The NRM's peripheral patronage in rural Uganda", Journal of Eastern African Studies, 10, No 4 (2016): 619-638.

World Bank. "Uganda's Unemployment Challenge". 2014. World Bank.

http://siteresources.worldbank.org/INTPROSPECTS/Resources/334934-1184090646382/Rep-of-Uganda2014-Ugandas-Employment-Challenge.pdf

World Bank. "Population Growth - annual (\%), 2015”, World Bank. Accessed on January 15, 2017. http://data.worldbank.org/indicator/SP.POP.GROW 